\title{
Right to Petition in India
}

\author{
By B. Venkatakrishnappa and M. Gurunath
}

A petiton necessarily involves a cause of action. Without cause of action, any individual or class of persons have no occasion to make out a petition. Therefore, every petition is made to an appropriate authority for fair consideration by the authority. In a democratic set up, a petition cannot be received by the authority as a material for a waste paper basket. Hence, the authority is bound to listen to the petitioners and give its reasoned opinion on the petition. Any system which just confers a right to petition must necessarily provide 3 consequential stages for the consideration of the petition:

1) hearing of the petition by the authority

2) on the basis of the hearing a reasoned or considered order of the authority or a "speaking order" must follow.

3) the authority must be able to five an effective remedy to redress the injustice done to the petitioners. If there is no effective remedy provided, then, the right to petition becomes meaningless or in other words if the reasoned order of the authority cannot be implemented the right to petition becomes imperfect.

In the Indian system, there are three possibilities of maintaining a petition to get the redressal of injustice done:

1) Right to petition to the Parliament or State Legislature, as the highest political body functioning under the constitution (Parliamentary Practice)

2) Right to petition for injustice meted out to an individual my making out a petition to the Ombudsman (Lokpal at the Centre and Lok Ayuktha at the State level)

3) Right to petition to the Supreme Court or the High Court under Public Interest Ligitation (Under Art. 321 S.C. \& Art. 226 to H.C.2) to get remedy.

\section{Right to Petition to Parliament or state Legislature}

Unlike the German Constitution (Basic Law) there is no specific article under the Indian Constitution conferring the right on an individual or a class of individuals to make out the petition to the legislature. However, in practice, the parliament and the State Legislature have directly received petitions conceming public issues and such petitions are placed

1 Article 32 of the Constitution of India.

2 Article 226 of the Indian Constitution. 
before Petitions Committee and the legislature and further suitable action is taken on this behalf. The parliament has always considered the petitions on its merits and in this way the parliament or the state legislature comes in contact with the people and will be able to know the actual public agony. The only disadvantage of this system is the recommendations of the Petitions Committee though considered, cannot be directly given effect to, but requires the approval of the Parliament, and the recommendations of the Committee are not binding. Similar is the situation under the German Basic Law. But this power to entertain a petition is treated as an inherrent power.

This system even in India has fairly worked out well, and the Petitions Committee has been able to settle a majority of complaints by providing mostly administrative reliefs. ${ }^{3} \mathrm{~A}$ noticeable phenomenon is the using off public grievances.

\section{Petitions to Lokpal \& Lokayukhat or the Indian Equivalent of Omudsman}

Petitions to these authorities are made under the relevant Lokayuktha Act of the State Legislatures. The Lokpal has not been appointed by the Centre for covering Lapses in the Union administration.

The state authorities provide a correcting remedy or making of a report regarding the Maladministration or corruption practice by the administrative authorities. The examination of the system has to be analysed only after considering the implementation and the functioning of the Lokayukhtas over a period of years. They yet do not possess the clout which the Parliamentary Commissioner of U.K. Possesses.

\section{Right to Petition (Constitution of India) Public Interest Litigation - New Dimension}

Article 32 of our Constitution confers a fundamental right to anyone to approach the Supreme Court of India for the enforcement of the fundamental rights. Article 226 confers constitutional rights to approach the High Court for enforcement of not only constitutional rights but other statutory rights as well. In both the cases, the courts can give remedy by issuing prerogative writs or other suitable orders. Under these two articles, the petitions have been maintained by individuals, social workers and organisations for the enforcement of a constitutional guarantee or for getting a remedy for public wrong. The courts have considered the petition / letters as a request for issue of writs and passed orders which have

3 The Hindu Report dated October 28, 1986, mentions that Karnataka State Legislature Petition Committee of Legislation, has given effective remedy in most of the cases. 
the sanction of courts. Under Article 141 of the Constitution the law declared by the Supreme Court is the law of land, as such it is binding on the authorities.

The High Court and the Supreme Court in the recent years (say from the past about 8 to 9 years) have recognised the right of a person to petition to the court for getting the remedy as the courts are receiving the petitions of alert individuals and social workers, and a new class of Public interest litigation has firmly been rooted.

Analysis of some of the decisions give a clear picture as to the development of the law in this regard. In Vardaraj Vs. Salem Municipality, the right of tax payer to qestion the misuse of funds of municipality was recognised4.

In K.R. Shenoy Vs. Udupi Municipality, the Supreme Court recognised the right of rate payer to qestion the action of municipality in granting cinema licence 5 .

In Ratlam Municipality case the standing (locus) of local resident to move the magistrate for prevention of public nusiance was recognised and orders passed to remedy the same6.

In Fertiliser Corporation Kamgar Union Case7, the workers union questioned certain sale of plants and machinery made by the Corporation (public enterprises). The Supreme Court obtained material facts and information and found that in the action that was assailed ther was no malafide and hence did not go into the right of workers to question the action of the management. In the same decision the minority judgement has clearly held the right of workers to question the action in cases under Article 226 of the Constitiution.

A letter written by a journalist claiming relief against demolition of a hutment, pavement dwellers of the municipal corporation at Bombay has been treated as a writ petition and the court has granted interim relief to the pavement dwellers in the Pavement Dwellers Cases 8 . In the Judges transfers case 9 a larger bench of the Supreme Court has held that the Practising Lawyers who are nothing short of partners in the task of administrative justice undertaken by the judges are vitally interested in the maintenance of a fearless and independent judiciary to ensure a fair and fearless justice to litigent. Hence in challenging the constitutionality of law Minister circular, and grant of short term extension to sitting additional judges, the lawyers have not merely sufficient interest but special interest of their own. They cannot be told off at the gates and the petitions are maintainable.

4 Varadarajan vs. Salem Municipality A I R 1973 Mad. 55.

5 K.R. Shenoy vs. Udupi Municipality A I R 1974 S.C. 2177.

6 Ratlam Municipality Case A I R 1980 S.C. 1982.

7 Fertilizer Corporation Kamagar Union Case A I R 1981 S.C.344.

8 A I R 1982 S.C. Page 188 Para 16.

9 Judges transfer case A I R 1982 S.C. 149. 
In Asiad Workers case ${ }^{10}$, the Supreme Court recognised, and made orders for implementation regarding the actual payment of minimum wages to workers and observance of labour law under the petition of an association viz., People's Union for Democratic Rights.

In another case the letter of the President of Peoples Union for Democratic Rights 11 along with a news paper report sent to the judge was taken as writ petition and orders passed to see the implementation of certain labour laws regarding migrant workers.

The Supreme Court has awarded Rs. 2,000/- as cost, granted to Free legal society for having vindicated the right of poor workers for implementation of Minimum wages Act 12 .

The workers of a company have a stake in the company, hence they have a right to petition to the company judge at the time of consideration of winding up petition, even though the Companies Act had not specifically conferred the right to workers. This is a land mark decision of the Supreme Court regarding Right to Petition13.

In Dr. Upendra Baxi's case14 letter written by the Professor and a social worker has been considered by the Supreme Court as a writ petition and orders passed for providing proper remedies to the inmates of the public remand homes.

In another judgement of 19th December, 1986, the People's Union for Democratic Rights filed an application under Article 32 of the Constitution alleging that 100 poor peasants who were conducting a meeting were fired upon by the police killing atleast 21 persons. This Union which was formed to protect fundamental rights, filed a direct petition in the Supreme Court of India for directions to be issued to the State of Bihar for immediate interim payment of compensation to the victims of heirs as in their view, such a step was essential in order to enable them to have the energy to prosecute their claims. The court readily agreed with the contention and directed the payment of compensation 15 .

\section{Summary}

From a study of such cases it can be seen how the Supreme Court has widened the concept of right to petition into a Constitutional reality in providing justice, equality, and liberty enshrined in the preamble. We can see clearly certain advantages in this system of petition under PIL.

10 Asiad Worker's case A I R 1982 S.C. 1473.

11 Labourers working on Salal Hydro Project vs. State A I R 1984 S.C. 177.

12 Ram Kumar Mishra vs. State A I R 1984 S.C. 537.

13 National Union of Textile Workers vs. Ramkrishnan.

14 Upendra Bhakshi's case, cited in: A I R 1982 S.C., page 188, para. 16.

15 People's Union for Democratic Rights A I R 1987 S.C. 355. 
Firstly, it is a cheap process. The cost of litigation is less, in some cases even letters / newspapers reports are treated as writ petitions.

Secondly, the process has been fairly quick as writ petitions have been treated on priority basis.

Thirdly, these petitions have not been subjected to procedural requirements as in the cases before Ombudsman or before Petitions Committee of Legislature.

Fourthly, the Supreme Court judgement have vindicated the rights of poor, downtrodons, illiterate or suppressed class who would not have had access to justice. This in tur has enlightened the conceptual thinking.

Fifthly, these judgements have a deterrent effect on the authorities in power not to act in unconstitutional way. Since the highest court of the land takes cognigance.

Sixthly, perhaps the remedies provided under these judgements would not have been available by any number of Petitions to committees of legislature or other authorities. The remedy provided is with the sanction of the Court whereas the Petitions Committee can only make a recommendatory order.

All these are founded upon the constitutional provisions of personal liberty and fundamental rights reminiscent of the american technique of working the due process clause.

\section{Conclusions}

The Right to Petition is an inherent right of every citizen of society since he is an unit of it. Under the Indian system, where there is low percentage of literacy, the society being heterogeneous and having people, who are backward, socially and economically, the Supreme Court of India, has developed a new branch of law, by recognising the right to petition to the highest tribunal for the enforcement of basic living rights. It has provided quick, direct and effective remedy. By acting in this manner, the Supreme Court has acted to uphold the Constitutional Rights and Right to Petition. This could be termed as the changing role the Supreme Court has played within the last Fifteen years. The Supreme Court has recognised the right to petition for the enforcement of certain basic rights as the most sacred right of the petitioner in India. Judicial activism has compensated for the lethargy of the legislatures.

The only apprehension is that the court's other constitutional functions may get scramped and probably newer legal techniques and tribunals have to be devised. 